\title{
Production of Gluten-Free Rolled Paper from Broken Rice by Using Different Hydrothermal Treatments
}

\author{
Amal M. H. Abdel-Haleem \\ Crops Technology Research Department, Food Technology Research Institute, Agricultural Research Centre, Al-Giza, Egypt
}

Email address:

amalefsic@yahoo.com

\section{To cite this article:}

Amal M. H. Abdel-Haleem. Production of Gluten-Free Rolled Paper from Broken Rice by Using Different Hydrothermal Treatments. International Journal of Nutrition and Food Sciences. Vol. 5, No. 4, 2016, pp. 255-263. doi: 10.11648/j.ijnfs.20160504.14

Received: May 26, 2016; Accepted: June 7, 2016; Published: June 20, 2016

\begin{abstract}
The aim of this study is to produce Gluten-Free rolled paper from broken rice by using different hydrothermal treatments. Pressure parboiling, dry roast parboiling, and popping treatments were applied to enhance the functionality of lowamylose broken rice flour. The effects of hydrothermal treatments on the morphological, physicochemical, as well as sensory properties of the produced Gluten-Free rolled papers were studied. Morphological examination of hydrothermal treated flours showed gelatinized and enlarged starch granules with different shapes, and fractures in the surface, especially in dry roasted parboiled flour. For chemical composition $(\mathrm{g} / 100 \mathrm{~g})$, protein $(6.7$ - 3.57), total starch (81.67- 76.36) and amylose (17.27 14.18) significantly decreased in rice papers produced from hydrothermal treated flours, while fat (1.67 - 1.82) and ash (1.62 2.68) significantly increased. In vitro starch digestibility showed a significant increase ( $80-99.73 \mathrm{~g}$ glucose/ $100 \mathrm{~g})$ in rice papers produced from dry roast parboiling and popping treatments. Rice paper batters produced from hydrothermal treatments had a noticeable viscosity pattern characterized by a non-Newtonian pseudoplastic flow behavior. A significant reduction in lightness value ( 89.77 to 60.42$)$ occurred, while a significant increase in redness ( 0.33 to 1.54$)$ and yellowness (3.75 - 20.59) values were observed in all rice papers produced from hydrothermal- treated flours. Tensile strength $\left(0.14-0.36 \mathrm{~N} / \mathrm{mm}^{2}\right)$ and $\%$ elongation at break (43-57\%) significantly increased in rice papers produced from parboiling treatments, while fracture toughness increased $\left(2.76-5.51 \mathrm{~N} / \mathrm{mm}^{3 / 2}\right.$ ) in rice paper produced from popping treatment. Sensory evaluation indicated significant improvement in freshness, rollability, and the overall scores in rice papers produced from parboiling treatments. Results could be a value addition for processing of low- amylose broken rice flour and delivering high quality rice paper to consumers who are more concerned about Gluten-Free products.
\end{abstract}

Keywords: Rice Paper, Heat Treatments, Morphological Examination, Physicochemical Properties, Sensory Evaluation

\section{Introduction}

Nowadays, the motivation for improving and developing Gluten-Free foods have attracted much research interest [1]. Especially, with rising number of patients with gluten sensitivity and celiac disease [2]. In addition to, the rapid change in consumer lifestyle, where gluten-free diet is also associated with weight management and overall health $[3,4]$.

Broken rice is a by-product produced during rice milling and polishing [5]. It has been used in the manufacturing of rice flour and modified starches, with the advantages of low cost and great availability, as a value addition to various industrial utilization [6-8]. Rice flour is a suitable ingredient to prepare gluten-free products, because of its tender taste, white color, easily digestible carbohydrates, and hypoallergenic activities $[1,9]$.

Rice paper based on rice flour or rice starch is a common food in East Asian and Southeast Asian cuisine, particularly in Vietnam and Thailand, and is gaining popularity in North America [10]. But, it is not popular in Arab countries, especially in Egypt. Rice paper is a large variety of filled, rolled appetizers as spring roll papers [11] or güllaç/ golash produced from wheat flour. The type of wrapper, fillings, and the cooking method used, as well as the name, differ considerably inside this large zone, according the culture of the area [12].

Manufacturing of rice paper from Egyptian rice varieties (Japonica type) and its by- products might confront a challenge relates to the lower- amylose content of these 
varieties. These varieties are the most widespread and preferable by the Egyptian consumer due to its cooking and eating characteristics, e.g. moistness, tenderness, glosses and taste $[13,14]$. However, flour from low- amylose rice has no potential for making usable rice paper [11, 15]. Besides, problems related to rice flour quality, where native rice flour has poor resistance to shear force, and low elastic gelforming ability. Also, most native starches have a marked tendency to lose their viscosity and thickening power during cooking [16-18].

Different hydrothermal treatments have been successfully applied to enhance the physicochemical and functionality of rice flours and starches $[17,19]$. Parboiling technique is a hydrothermal process consisting of soaking, heating and drying operations modifying the qualitative and processing behavior of rice flour $[20,21]$. On parboiling, the starch granules are gelatinized, retrograded, and considerable changes occur in the pasting parameters due to the orderdisorder transitions taking place at the molecular level [20, 22]. These changes play an important role in the subsequent processing operations, such as, cooking and eating qualities $[23,24]$. Popping in the presence of salt solutions is another hydrothermal treatment. During popping gelatinization and drying occur simultaneously, and the popped products are characterized by good texture, highly desirable aroma, taste and acceptability [25, 26].

However, despite the possibilities of applying the hydrothermal treatments for enhancement the functions of the rice flours, these treatments have never been studied for the production of rice papers. Therefore, the aim of the present study is to produce Gluten-Free rolled paper from low- amylose broken rice flour using hydrothermal treatments namely; pressure parboiling; dry roast parboiling and popping, to enhance the functionality of the broken rice flour. Besides, studying the effect of these hydrothermal treatments on the morphological, physicochemical, as well as sensory properties of the produced Gluten-Free rolled papers.

\section{Materials and Methods}

\subsection{Materials}

Broken rice from low amylose $(15.27 \%)$ rice variety Sakha 104 (Japonica genotype) was obtained after the milling and polishing process of brown rice, local milling processing unit, Damietta, Egypt. The percentage of brokens to rice kernel is $27 \%$. Corn starch, corn oil, salt, soft white salty cheese, peppermint and vanilla were purchased from the supermarket, Al-Giza, Egypt. Pancreatic $\alpha$ - amylase (1: 2000 activity) was obtained from Oxford Lab. Chem, India. Amyloglucosidase (amylo 300) was obtained from Biocon India Pvt. Ltd., India. Amylose and $D$ - glucose standards were obtained from Sigma- Aldrich, St. Louis, MO, USA. A glucose oxidase/ peroxidase kit was obtained from Biodiagnostic Co., Dokki- Al Giza, Egypt. All other chemicals used were of analytical reagent grade.

\subsection{Methods}

\subsubsection{Hydrothermal Treatments of Broken Rice}

\section{Pressure Parboiling Treatment of Broken Rice}

The pressured parboiled broken rice was prepared as described by Chinnaswamy \& Bhattacharya (1986) [27]. About one $\mathrm{kg}$ of broken rice was soaked in double amount of water for $30 \mathrm{~min} / 37^{\circ} \mathrm{C}$, then water was drained-of, and broken rice was spread on a wire mesh tray and steamed in an autoclave at $121^{\circ} \mathrm{C} / 20 \mathrm{~min}$ under a pressure steaming of 15 psi. Soaking was performed in triplicate. Pressured parboiled broken rice was dried at $40^{\circ} \mathrm{C}$ in an air convection oven till dry.

\section{Dry Roast Parboiling Treatment of Broken Rice}

Dry roasted parboiled broken rice was prepared as described by Shashikala et al. (2005) [28]. About one $\mathrm{kg}$ of broken rice was soaked in water $(1: 10)$ at $\sim 98^{\circ} \mathrm{C}$ (the temperature after mixing was $70^{\circ} \mathrm{C}$ ). The container was well covered to allow slow cooling for $18 \mathrm{~h}$. Soaking was performed in triplicate. The water was drained, and the parboiled broken rice was roasted at $165^{\circ} / 3 \mathrm{~h} \mathrm{C}$ in an air convection oven. Then the temperature was reduced to $40^{\circ} \mathrm{C}$ until drying.

\section{Popping Treatment of Broken Rice}

The popped broken rice was obtained by modifying the method of Hsieh \& Bor (1991) [29]. About one $\mathrm{kg}$ of broken rice was conditioned from initial moisture content $10.9 \%$ to moisture level from $14-14.5 \%$ by adding a measured amount of water $(42 \mathrm{ml})$ containing salt solution $(2 \mathrm{~g} \mathrm{salt} / 100 \mathrm{ml}$ water), then tempered overnight in an airtight container at room temperature. Conditioning was performed in triplicate. It was then subjected to high temperature $220^{\circ} \mathrm{C} / 2 \mathrm{~min}$ in a convection hot air popping maker (Home PM-1891, $1200 \mathrm{~W}$, 220 V, 50 HZ, China).

All samples from untreated and hydrothermal treated broken rice were milled with laboratory hammer mill and sieved through $850 \mu \mathrm{m}$ sieve. The produced flours were kept in plastic bags at room temperature for further use.

\subsubsection{Scanning Electron Microscopic (SEM) Examination}

Morphology of untreated and hydrothermal treated broken rice flours were examined using Scanning Electron Microscope (SEM) according to Dronzek et al. (1972) [30]. Samples were sputter-coated (SPI- Module ${ }^{\mathrm{TM}}$ Sputter Coater, USA) with gold at vacuum evaporator then examined using SEM (JEOL, JSM- 5200, Tokyo, Japan) at $25 \mathrm{kV}$ accelerating voltage with different magnification power at 500, 750,1000 and 5000X.

\subsubsection{Production of Gluten-Free Rolled Papers}

Gluten-Free rolled papers were prepared from untreated and hydrothermal- treated broken rice flours according to Cameron \& Hosseinian (2013) [10]. The proper composition to formulate the batter were broken rice flour $(64 \mathrm{~g} / 100 \mathrm{~g})$, corn starch (30 g/100 g), corn oil (3.5 g/ $100 \mathrm{~g})$, salt (2 $\mathrm{g} / 100 \mathrm{~g})$, vanilla $(0.5 \mathrm{~g} / 100 \mathrm{~g})$, and water. The batter was 
mixed with whisk till proper consistency, spread thinly with a ladle on a tightly stretched cloth, then covered with a lid and steamed for $1-2 \mathrm{~min} / 80^{\circ} \mathrm{C}$ over a water bath. The rice paper skins were allowed to cool and kept in plastic film to make the sensory evaluation and mechanical properties. The rest rice paper skins were dried at ambient temperature for $18 \mathrm{~h}$, milled and kept in plastic bags at $5^{\circ} \mathrm{C}$ for further analysis.

\subsubsection{Proximate Analysis}

Moisture, protein, fat, crude fiber, and ash contents of the broken rice and the rice papers prepared from untreated and hydrothermal- treated flours were determined according to the methods of AOAC (2007) [31]. The nitrogen content was estimated by Kjeldahl method, and the nitrogen conversion factor of the crude protein calculation was 5.75. The amylose content was determined according to the method of Juliano (1971) [32] based on the blue color reaction with iodine. The results were expressed on a dry basis, and all analysis of different samples were averaged from three replicates.

\subsubsection{In Vitro Starch Digestibility and Total Starch}

In vitro starch digestibility of broken rice flour and GlutenFree rice papers were determined using pancreatic amylase and amyloglucosidase according to the modified method of Englyst et al. (1992) [33]. A suitable amount of defatted sample $(0.5 \mathrm{~g})$ was dispersed in $30 \mathrm{ml}$ of $0.2 \mathrm{M}$ sodium acetate buffer, $\mathrm{pH}$ 6.0. Freshly prepared solution of pancreatic $\alpha$ - amylase and amyloglucosidase $(5 \mathrm{ml})$ was added to the sample suspension and incubated at $37^{\circ} \mathrm{C} / 20$ then $120 \mathrm{~min}$. The obtained aliquots $(0.5 \mathrm{ml})$ were mixed with $4 \mathrm{ml} 80 \%$ ethanol and centrifuged at $4000 \times \mathrm{g} / 10 \mathrm{~min}$. The glucose in the mixture was measured using glucose oxidase/ peroxidise assay and standard curve of $D$ - glucose. Total starch was estimated following same procedure using amyloglucosidase only. The glucose released (g/ $100 \mathrm{~g}$ ) was calculated using the equation (1):

$$
\begin{aligned}
& \text { Glucose released (g/ } 100 \mathrm{~g} \text { ) } \\
& =\frac{\text { total weight of glucose in supernatant } \times 0.9}{\text { dry weight of starch }} \times 100
\end{aligned}
$$

where 0.9 is the molar mass conversion from glucose to the starch monomer unit.

\subsubsection{Viscoelastic Properties of the Gluten-Free Rice Paper Batters}

Viscoelastic properties of the gluten-free rice paper batters were measured using Brookfield Engineering labs DV-III Ultra Rheometer as indicated in Brookfield Manual (1998) [34]. The sample was placed into a small adapter at $37^{\circ} \mathrm{C}$, and the SC4-21 spindle was selected for the measurement. The viscometer was operated between 10 and 60 RPM. Apparent viscosity and shear rate data were obtained directly from the instrument.

\subsubsection{Color Measurement of Gluten-Free Rice Papers}

The colorimetric measurements of Gluten-Free rice papers were measured in triplicate using a colorimeter (CR-10,
Konica Minolta Sensing Inc., Japan according to McGurie (1992) [35]. The color values were recorded as $\mathrm{L}^{*}=$ lightness $(0=$ black, $100=$ white $), a^{*}\left(-a^{*}=\right.$ greenness, $+a^{*}=$ redness $)$ and $b^{*}\left(-b^{*}=\right.$ blueness, $+b^{*}=$ yellowness $)$.

\subsubsection{Mechanical Properties of Gluten-Free Rice Papers}

The mechanical properties of the Gluten-Free rice papers were tested using a texture analyzer Universal Testing Machine, Cometech, Taiwan, according to the method of ASTM D882 (2010) [36]. Gluten-Free rice paper samples were cut into small strips, $3 \mathrm{~cm} \times 1 \mathrm{~cm}$ and the measurement of each strip averaged from 5 replicates. The ends of the strips were clamped between cardboard grips using doubleside adhesive tape such that the final area exposed was 25.4 $\mathrm{mm} \times 50.0 \mathrm{~mm}$ with a load cell of $25 \mathrm{~kg}$. The initial grip separation of the tensile mode was set at $50 \mathrm{~mm}$, and force $(\mathrm{N})$ and elongation $(\mathrm{mm})$ were recorded during extension at $20 \mathrm{~mm} / \mathrm{min}$ up to break. From the resulting forced- time curve, tensile strength $\left(\mathrm{N} / \mathrm{mm}^{2}\right)$, elongation at break $(\mathrm{E} \%)$, and fracture toughness $\left(\mathrm{N} / \mathrm{mm}^{3 / 2}\right)$ were calculated.

\subsubsection{Sensory Evaluation of Gluten-Free Rolled Papers}

Gluten-Free rolled papers were prepared with a filling containing white cheese and peppermint paste, glazed with butter and baked in an oven grill till golden surface appeared. A 9-point hedonic scale was used for determining the sensory evaluation for color, taste, aroma, firmness, freshness, rollability and overall liking of Gluten-Free rolled papers. The sensory evaluation of samples was conducted according to Cameron \& Hosseinian (2013) [10]. A ten member sensory panel was formed from the staff of Food Technology Research Institute, Agricultural Research Center, Al- GizaEgypt. All samples were coded with three-digit random numbers and presented to panelists on a tray at ambient temperature. Orders of servings were completely randomized. Rollability liking score was performed on unbaked samples by how easy a sample is wrapped or rolled and filled with cheese and peppermint paste without tearing. For each sample, panelists scored their liking of these characteristics using the 9-point hedonic scale $(1=$ dislike extremely, $5=$ neither like nor dislike and $9=$ like extremely). An average of 10 scores for each attribute was reported.

\subsubsection{Statistical Analysis}

All data were subjected to analysis of variance. Duncan's multiple range tests at $(P \leq 0.05)$ level to compare between means. The analysis was carried out using the PRO ANOVA procedure of SAS Program (1996) [37].

\section{Results and Discussion}

\subsection{Scanning Electron Microscopic (SEM) Examination of Untreated and Hydrothermal Treated Flours}

Figure 1 presents the morphological examination of untreated and hydrothermal treated flours obtained by SEM. As shown in Fig. 1 starch granules had smaller sizes, 
appeared to be compactly packed in untreated flour. In pressure parboiled flour, the starch granules seem to be partially gelatinized [38]. In dry roasted parboiled flour, the starch granules were the most expanded, smooth and had polygonal and angular shapes. Besides, some fracture on starch granule surface. This might be as a result of parboiling followed by roasting treatment used in modification method, which caused swollen or gelatinized granules around the surface [39]. In popped flour, the starch granules had variable sizes, randomly located, gradually gelatinized and melted substance appeared. This might be when samples suddenly subjected to very high temperature, the water in the soaked broken rice simultaneously participated in starch gelatinization as well as tried to evaporate out of the starch granules in all possible directions, causing rapid drying of the gelatinized granules $[19,40,41]$.

\subsection{Chemical Composition of Broken Rice Flour and Untreated and Hydrothermal Treated Gluten-Free Rice Papers}

Table 1 represents the chemical composition of broken rice flour and rice papers produced from untreated and hydrothermal treated flours on dry weight basis. It could be noticed that broken rice flour had $7.40 ; 0.47 ; 0.49 ; 0.73$; 84.81 and $15.27 \mathrm{~g} / 100 \mathrm{~g}$ for protein; fat; ash; crude fiber, total starch, and amylose, respectively. Although, the value of broken rice is lower than whole kernel [42], but broken rice has the same chemical composition as the polished one [5]. Nessreen et al. (2014) [43] found that the Egyptian rice variety Sakha 104 (Japonica genotype) had 7.25\% protein, $0.45 \%$ fat, $0.50 \%$ ash, $0.66 \%$ crude fiber, and $18.20 \%$ amylose, which is near from our results.

Regarding rice paper produced from untreated flour, Nagano et al. (2000) [11] found that the Japanese rice paper produced from low- amylose rice (Akebono variety) had $6.94 \%$ crude protein, and $17.52 \%$ amylose, which is close to our results. For rice papers produced from hydrothermal treated flours, a significant decrease was found in protein, total starch, and amylose contents. While, a significant increase was found in fat and ash contents. However, crude fiber not affected. The decrease in protein might imparted by heat denaturation, forming starch- protein complex, and adhesion/ cohesion of proteins with other components [44].
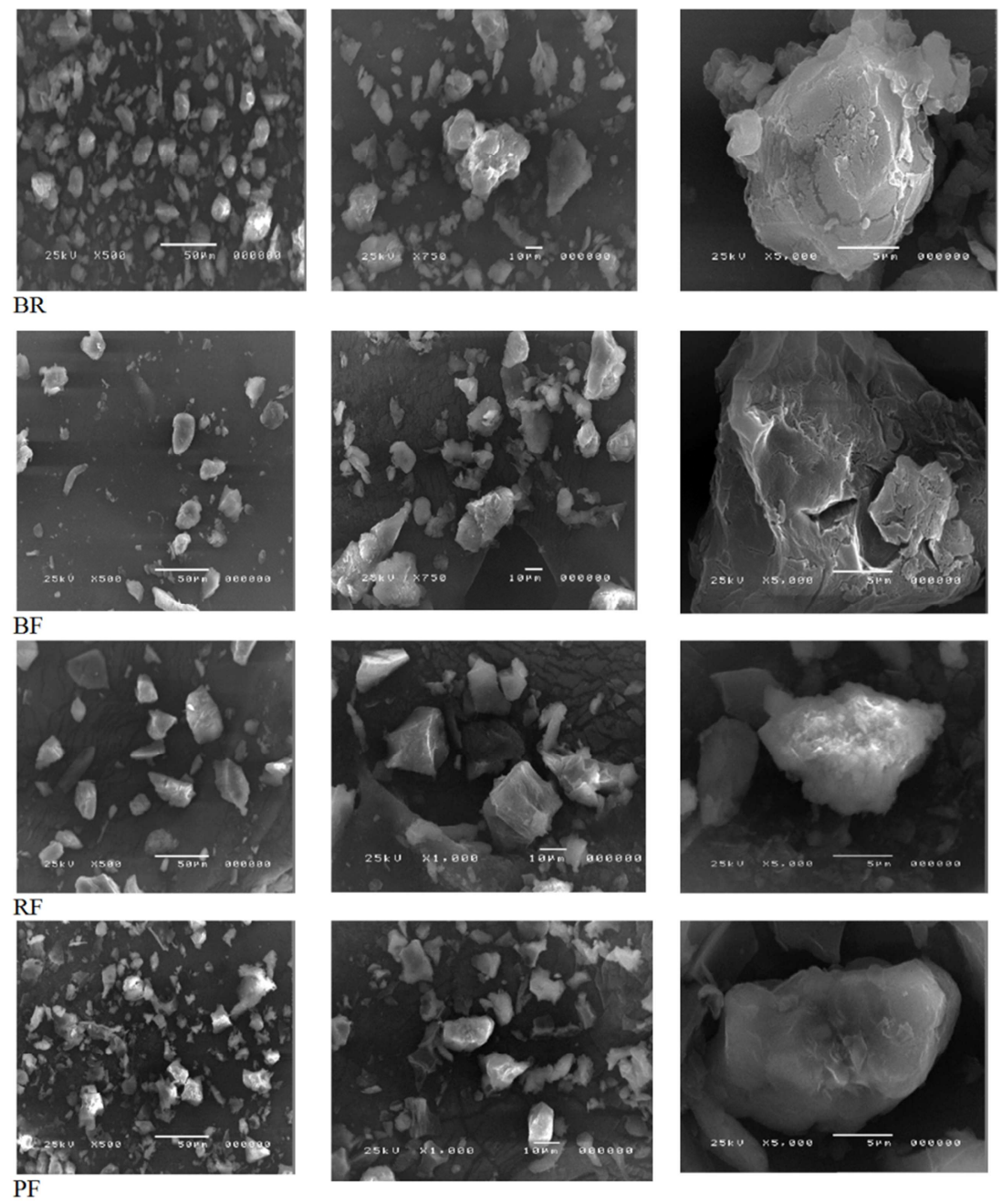

Figure 1. Scanning Electron Microscopic (SEM) Examination of rice flours. 
Besides, formation of melanoidin compounds in Maillard reaction between reducing sugars from the heated starch and the amino group in the proteins on high heat processing [19]. The decreased in total starch and amylose contents is attributed either to the leaching out of starch and amylose into the soaking water [23]. Or the more severe the processing condition/ gelatinization process, the more rapid the digestion of starch, the more decrease in soluble amylose
$[45,46]$. The increase in fat content is imparted by the leaching and rupturing of the fat globules during the hydrothermal treatment [47] and the addition of corn oil to the batter.

The increase in ash content is due to the addition of salt in the batter [12], it was evident more in popped rice paper because of the conditioning in salt.

Table 1. Chemical composition of broken rice flour and untreated and hydrothermal treated Gluten-Free rice papers on dry weight.

\begin{tabular}{|c|c|c|c|c|c|c|c|}
\hline Samples & $\begin{array}{l}\text { Protein } \\
(\mathrm{g} / \mathrm{100g})\end{array}$ & $\begin{array}{l}\text { Fat } \\
(\mathrm{g} / 100 \mathrm{~g})\end{array}$ & $\begin{array}{l}\text { Ash } \\
(\mathrm{g} / \mathrm{100g})\end{array}$ & $\begin{array}{l}\text { Crude fiber } \\
(\mathrm{g} / 100 \mathrm{~g})\end{array}$ & $\begin{array}{l}\text { Total starch } \\
(\mathrm{g} / \mathrm{100g})\end{array}$ & $\begin{array}{l}\text { Amylose } \\
(\mathrm{g} / \mathrm{100g}) \\
\end{array}$ & $\begin{array}{l}\text { SD* } \\
\text { (g glucose/ 100g) }\end{array}$ \\
\hline BRF & $7.40 \pm 0^{\mathrm{a}}$ & $0.47 \pm 0^{d}$ & $0.49 \pm 0.02^{\mathrm{e}}$ & $0.73 \pm 0.02^{\mathrm{a}}$ & $84.81 \pm 0.02^{\mathrm{a}}$ & $15.27 \pm 0.3^{\mathrm{c}}$ & $37.7 \pm 0.1^{\mathrm{e}}$ \\
\hline $\mathrm{C}$ & $6.7 \pm 0.06^{\mathrm{b}}$ & $1.67 \pm 0.06^{\mathrm{c}}$ & $1.62 \pm 0.04^{\mathrm{d}}$ & $0.27 \pm 0.02^{\mathrm{bc}}$ & $81.67 \pm 0.51^{\mathrm{b}}$ & $17.27 \pm 0.3^{\mathrm{a}}$ & $80 \pm 0.4^{\mathrm{d}}$ \\
\hline B & $4.33 \pm 0.27^{\mathrm{d}}$ & $1.73 \pm 0^{\mathrm{b}}$ & $2.37 \pm 0.02^{\mathrm{b}}$ & $0.24 \pm 0.02^{\mathrm{c}}$ & $76.62 \pm 0.3^{d}$ & $15.67 \pm 0.03^{b}$ & $85.6 \pm 0.8^{c}$ \\
\hline $\mathrm{R}$ & $5.58 \pm 0.01^{\mathrm{c}}$ & $1.8 \pm 0.01^{\mathrm{a}}$ & $2.2 \pm 0.08^{\mathrm{c}}$ & $0.29 \pm 0.01^{\mathrm{b}}$ & $79.43 \pm 0.02^{\mathrm{c}}$ & $14.28 \pm 0.03^{\mathrm{d}}$ & $99.73 \pm 1.4^{\mathrm{a}}$ \\
\hline $\mathrm{P}$ & $3.57 \pm 0.32^{\mathrm{e}}$ & $1.82 \pm 0.01^{\mathrm{a}}$ & $2.68 \pm 0.01^{\mathrm{a}}$ & $0.24 \pm 0.01^{\mathrm{c}}$ & $76.36 \pm 0.37^{\mathrm{d}}$ & $14.18 \pm 0.1^{\mathrm{d}}$ & $90.86 \pm 0.90^{\mathrm{b}}$ \\
\hline
\end{tabular}

* SD: starch digestibility

BRF- broken rice flour, C- untreated rice paper, B- pressured parboiled rice paper, R- dry roasted parboiled rice paper, P- popped rice paper. Data are presented as means \pm SDM $(\mathrm{n}=3) \&$ Means within a column with different letters are significantly different at $P \leq 0.05$.

\subsection{In Vitro Starch Digestibility of Broken Rice Flour and Untreated and Hydrothermal-Treated Gluten-Free Rice Papers}

In vitro starch digestibility results (g glucose / $100 \mathrm{~g}$ sample) are presented in Table 1. Data reveled lower in vitro starch digestibility of broken rice flour and rice paper produced from untreated flour. This is may be due to the native structure of the starch which is semi-crystalline in nature; where the starch granule is usually surrounded by a protein matrix making it less susceptible to enzymatic digestion [48]. On the other hand, in vitro starch digestibility significantly increased in rice papers produced from hydrothermal treated flours, and the most significant increase was pronounced more in dry roasted parboiling treatment followed by popped one. This is may be attributed to that soaking in hot water and pressure cooking causes significant increase in starch digestibility [49], where the starch gelatinization has taken place, accompanied with molecular breakdown resulted in higher exposure of the starch fractions to the digestive enzymes [19], and with the increase in the degree of parboiling, the digestibility increased [46]. The reason for lesser digestibility shown by popped rice paper, probably due to that tempering in salt, followed by popping with hot air convection, helped in formation of resistance starch [50]. This resistant form of starch is considered dietary starch, that resist the digestion and give lesser digestibility than dry roast parboiling treatment [51].

\subsection{Viscoelastic Properties of Gluten-Free Rice Paper Batters}

Viscoelastic properties of gluten-free rice paper batters are presented in Fig. 2. It could be seen that apparent viscosity of rice paper batters was decreased with increasing shear rates, revealing the non-Newtonian pseudoplastic or shear-thinning behavior of the batters and could be modeled as power lawfluid $\left(\mathrm{n}=\mathrm{kr}^{\mathrm{n}-1}\right)$. The increased shear rate deforms and rearranges starch particles, resulting in lower flow resistance and consequently lower apparent viscosity [52]. Decreased apparent viscosity is beneficial for spreading the rice batter as well giving a suitable texture to rice paper [53]. Another concern, that the hydrothermal treated rice papers batter had a higher apparent viscosity than untreated sample. This is attributed to that the hydrothermal treatment caused swelling of starch granules, released soluble components and amylose, absorbed more water, thus decreased the free available water in the system and developed more apparent viscosity than untreated rice paper batter [54]. Kuenchan et al. (2009) [55] indicated that gelatinized starch shown higher swelling power and possessed more consistency and apparent viscosity than native rice starch.

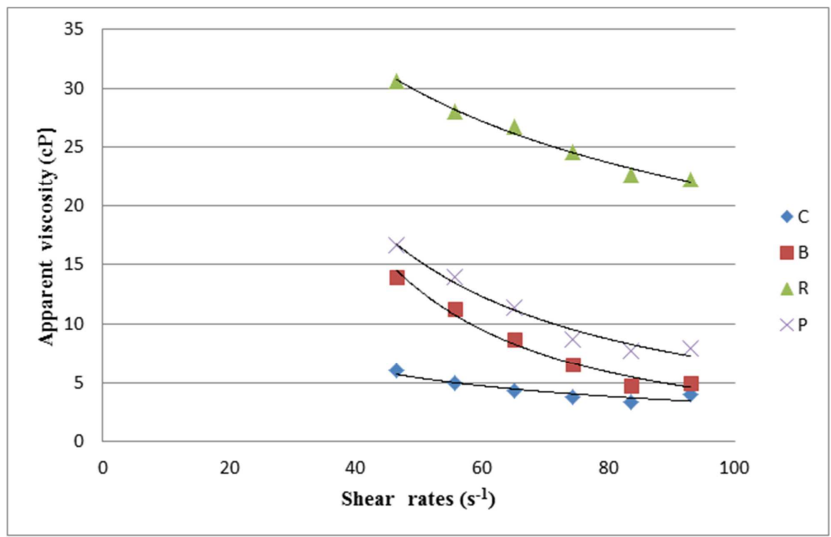

Figure 2. Apparent viscosity of the Gluten-Free rice paper batters at different shear rates.

C- untreated rice paper, B- pressured parboiled rice paper, R- dry roasted parboiled rice paper, $\mathrm{P}$ - popped rice paper.

\subsection{Color Measurement of Gluten-Free Rice Papers}

Table 2 shows the color measurements of Gluten-Free rice papers produced from untreated and hydrothermal- treated 
flours. Data revealed significant reduction in lightness value $\left(L^{*}\right)$ in the dry roasted parboiled and popped treatments. That reduction was due to starch gelatinization $[19,20]$. Islam et al. (2004) [56] reported that lightness value directly correlated with the extent of gelatinization during parboiling, besides time and temperature of soaking, heating, and drying [57]. From the same Table significant increase in positive values of $a^{*}$ (redness), and $b^{*}$ (yellowness), was observed in all hydrothermal treatments. This is imparted by Maillard browning on high heat processing between reducing sugar from the heated starch, and the amino group of the proteins, during modification [39, 58, 59].

Table 2. Color measurements of untreated and hydrothermal treated GlutenFree rice papers.

\begin{tabular}{llll}
\hline Samples & $\boldsymbol{L}^{*}$ & $\boldsymbol{a}^{*}$ & $\boldsymbol{b}^{*}$ \\
\hline $\mathrm{C}$ & $89.77 \pm 0.24^{\mathrm{a}}$ & $0.33 \pm 0.04^{\mathrm{c}}$ & $3.75 \pm 0.07^{\mathrm{d}}$ \\
$\mathrm{B}$ & $74.77 \pm 0.51^{\mathrm{b}}$ & $0.37 \pm 0.16^{\mathrm{b}}$ & $5.58 \pm 0.21^{\mathrm{c}}$ \\
$\mathrm{R}$ & $68.6 \pm 1.26^{\mathrm{c}}$ & $0.54 \pm 0.02^{\mathrm{b}}$ & $7.64 \pm 0.07^{\mathrm{b}}$ \\
$\mathrm{P}$ & $60.42 \pm 2.27^{\mathrm{d}}$ & $1.54 \pm 0.47^{\mathrm{a}}$ & $20.59 \pm 1.62^{\mathrm{a}}$ \\
\hline
\end{tabular}

$\mathrm{L}^{*}=$ lightness $(0=$ black, $100=$ white $), \mathrm{a}^{*}\left(-\mathrm{a}^{*}=\right.$ greenness, $+\mathrm{a}^{*}=$ redness $)$ and $b^{*}\left(-b^{*}=\right.$ blueness, $+b^{*}=$ yellowness $)$.

$\mathrm{C}$ - untreated rice paper, B- pressured parboiled rice paper, R- dry roasted parboiled rice paper, $\mathrm{P}$ - popped rice paper.

Data are presented as means $\pm \operatorname{SDM}(n=3) \&$ Means within a column with different letters are significantly different at $P \leq 0.05$.

\subsection{Mechanical Properties of Gluten-Free Rice Papers}

The mechanical properties of Gluten-Free rice papers are presented in Table 3. The data revealed that tensile strength, which assessed the maximum stress that the rice paper can support [60], significantly increased in rice papers produced from hydrothermal treatments. These results indicated that the treated rice papers exhibited proper mechanical strength. That ensure its integrity and the resistance to fracture and cracks especially, during storage and reduces the defects, such as pinholes or fissures [61-63]. This is might be relates to the use of the gelatinized flour obtained by the hydrothermal treatments, which causes starch retrogradation [64] coupled with the interaction between rice flour and corn starch as a polysaccharide or polymer which useful to improve the mechanical properties [9].

One of the most remarkable features of good rice paper is a high elasticity [53], the elongation at break (\%) which expresses the ability of a material to resist changes of shape without crack formation [36] increased much significant in pressured parboiled and dry roasted parboiled treatments.
These results meaning the guarantees of adequate viscous, elastic and flexibility properties of these rice paper samples to possible deformation without breaking during filling [63]. On the other hand, the fracture toughness which measures the energy required to cause fracture [65] was significantly decreased in both parboiled treatments and increased in popped treatment. This might be related to the massive temperature used in popping treatment followed by rapid drying that increased the hardness of the rice paper, in turn, it absorbed more energy and consequently required a greater energy input to create fractures [66].

Table 3. The mechanical properties of Gluten-Free rice papers.

\begin{tabular}{llll}
\hline Samples & $\begin{array}{l}\text { Tensile strength } \\
\left(\mathbf{N} / \mathbf{m m}^{\mathbf{2}}\right)\end{array}$ & $\begin{array}{l}\text { Elongation } \\
(\mathbf{\%})\end{array}$ & $\begin{array}{l}\text { Fracture toughness } \\
\left(\mathbf{N} / \mathbf{m m}^{3 / 2}\right)\end{array}$ \\
\hline $\mathrm{C}$ & $0.14 \pm 0.08^{\mathrm{c}}$ & $43 \pm 0.07^{\mathrm{c}}$ & $3.64 \pm 0.25^{\mathrm{b}}$ \\
$\mathrm{B}$ & $0.34 \pm 0.07^{\mathrm{a}}$ & $48 \pm 0.13^{\mathrm{b}}$ & $2.93 \pm 0.24^{\mathrm{c}}$ \\
$\mathrm{R}$ & $0.36 \pm 0.13^{\mathrm{a}}$ & $57 \pm 0.19^{\mathrm{a}}$ & $2.76 \pm 0.23^{\mathrm{c}}$ \\
$\mathrm{P}$ & $0.16 \pm 0.05^{\mathrm{b}}$ & $43 \pm 0.05^{\mathrm{c}}$ & $5.51 \pm 0.17^{\mathrm{a}}$ \\
\hline
\end{tabular}

C- untreated rice paper, B- pressured parboiled rice paper, R- dry roasted parboiled rice paper, P- popped rice paper Data are presented as means \pm $\operatorname{SDM}(\mathrm{n}=5) \&$ Means within a column with different letters are significantly different at $P \leq 0.05$.

\subsection{Sensory Evaluation of Gluten-Free Rolled Rice Papers}

Table 4 represents the sensory evaluation of gluten-free rolled papers. Statistical analysis showed that there were some significant sensory differences between the rolled rice papers produced from untreated and hydrothermal- treated flours $(\mathrm{P} \leq 0.05)$.

The differences in color between untreated and treated rice papers attributed to the changes in color values as mentioned before. The dry roasted parboiled and pressure parboiled rice papers were greatly improved in freshness and rollability when compared to the untreated rice papers. The improvement occurred in rollability might be due to the significant increase in elongation at break (\%) as mentioned in the mechanical properties. Taste, aroma, and firmness of the dry roasted parboiled rice paper received higher ratings; however, it did not differ much significant in compared to untreated rice paper. On the other hand popped rice paper received the lowest score and this might be due to the use of high temperature during the modification, that increased the toughness, in turn, decreased the firmness and freshness, as well as the rollability. The overall scores of the sensory aspects of dry roasted parboiled and pressured parboiled rice papers were preferred over the untreated rice paper.

Table 4. Sensory evaluation of gluten-free rolled rice papers.

\begin{tabular}{|c|c|c|c|c|c|c|c|}
\hline Samples & color & taste & aroma & Firmness & freshness & rollability & OAA* \\
\hline $\mathrm{C}$ & $8.54 \pm 0.8^{b}$ & $8.18 \pm 0.9^{\mathrm{a}}$ & $8.36 \pm 0.8^{\mathrm{a}}$ & $8.64 \pm 0.5^{\mathrm{a}}$ & $7.77 \pm 1^{\mathrm{c}}$ & $7.82 \pm 1^{b}$ & $7.73 \pm 1.1^{b}$ \\
\hline B & $8.18 \pm 1^{c}$ & $8.36 \pm 0.8^{\mathrm{a}}$ & $8.1 \pm 1.1^{\mathrm{a}}$ & $7.59 \pm 1^{b}$ & $8.55 \pm 0.5^{\mathrm{ab}}$ & $8.68 \pm 0.6^{\mathrm{a}}$ & $8.41 \pm 0.7^{\mathrm{a}}$ \\
\hline $\mathrm{R}$ & $8.63 \pm 0.7^{\mathrm{a}}$ & $8.45 \pm 0.7^{\mathrm{a}}$ & $8.63 \pm 0.5^{\mathrm{a}}$ & $8.73 \pm 0.5^{\mathrm{a}}$ & $8.82 \pm 0.4^{\mathrm{a}}$ & $8.82 \pm 0.4^{\mathrm{a}}$ & $8.45 \pm 0.7^{\mathrm{a}}$ \\
\hline $\mathrm{P}$ & $7.59 \pm 0.8^{\mathrm{d}}$ & $7.63 \pm 1.2^{\mathrm{b}}$ & $8.14 \pm 1^{\mathrm{a}}$ & $6.95 \pm 1.6^{\mathrm{b}}$ & $7.68 \pm 1.6^{\mathrm{c}}$ & $7.27 \pm 0.9^{\mathrm{b}}$ & $7.41 \pm 0.9^{\mathrm{bc}}$ \\
\hline
\end{tabular}

*OAA- overall acceptability.

C- untreated rice paper, B- pressured parboiled rice paper, $\mathrm{R}$ - dry roasted parboiled rice paper, $\mathrm{P}$ - popped rice paper. ( $\mathrm{n}=10,9$ points structured scale).

Data with different superscript are significantly different at $P \leq 0.05$. 


\section{Conclusion}

Rice papers produced from pressured parboiled, dry roasted parboiled, and popped broken rice flours were compared to rice paper produced from native broken rice flour, in term of morphological, physicochemical, and sensory properties. The morphology of the treated broken rice flour demonstrated gelatinized and developed starch granules, with various shapes and cracks, particularly in dry roasted parboiled one. Rice papers obtained from hydrothermal treated broken rice flours had lower protein, starch and amylose contents, and higher fat, ash, and in vitro starch digestibility in compared to rice paper obtained from native broken rice flour. Apparent viscosity of treated rice paper slurry had a non-Newtonian shear-thinning behavior, modeled as a power law fluid. Not only, the parboiling techniques increased the elasticity and resistance to longitudinal stress of the rice papers, but also, they achieved the highest sensory hedonic score. Popped technique increased the energy required to fracture the rice paper, but it achieved the lowest sensory hedonic score. The results of this study could be useful in improvement of rice paper processing via parboiling and popping techniques. Besides, it added value for who are concerned about Gluten-Free products.

\section{References}

[1] Rosell, C. M., Barro, F., Sousa, C., \& Mena, M. C. (2014). Cereals for developing gluten-free products and analytical tools for gluten detection. Journal of Cereal Science, 59, 354364.

[2] Lebwohl, B., Ludvigsson, J. F., \& Green, P. H. R. (2015). Celiac disease and non-celiac gluten sensitivity. BMJ, 351, h4347.

[3] Lamacchia, C., Camarca, A., Picascia, S., Di Luccia, A. \& Gianfrani, C. (2014). Cereal-based gluten-free food: how to reconcile nutritional and technological properties of wheat proteins with safety for celiac disease patients- a review. Nutrients, 6, 575- 590.

[4] Murray, J. A., Watson, T., Clearman, B., \& Mitros, F (2015). Effect of a gluten-free diet on gastrointestinal symptoms in celiac disease. The American Journal of Clinical Nutrition, 79, 669- 673 .

[5] Marco, M. De., Peiretti, P. G., Miraglia, N., \& Bergero, D. (2014). Apparent digestibility of broken rice in horses using in vivo and in vitro methods. Animal, 8, 245- 249.

[6] Limberger, V. M., Silva, L. P., Emanuelli, T., Comarela, C. G., \& Patias, L. D., (2008). Physical and chemical modification of starch from broken rice for use in the food industry. New Chemical, 31, 84-88.

[7] Bhatnagar, A. S., Prabhakar, D. S., Kumar, P. K., Raja Rajan, R. G. \& Krishna, G. A. G. (2014). Processing of commercial rice bran for the production of fat and nutraceutical rich rice brokens, rice germ and pure bran. LWT - Food Science and Technology, 58, 306-311.
[8] Ashour, E. A., Reda, F. M. \& Alagawany, M. (2015). Effect of graded replacement of corn by broken rice in growing Japanese quail diets on growth performance, carcass traits and economics. Asian Journal of Animal Sciences, 9 (6), 404-411.

[9] Loubes, M. A., Flores, S. K., Tolaba, M. P., (2016). Effect of formulation on rice noodle quality: Selection of functional ingredients and optimization by mixture design. LWT - Food Science and Technology, 69, 280-286.

[10] Cameron, S. J. \& Hosseinian, F. (2013). Potential of flaxseed in the development of omega-3 rice paper with antioxidant activity. LWT - Food Science and Technology, 53, 170-175.

[11] Nagano, H., Shoji, Z., Tamura, A., Kato, M., Omori, M., To, K., et al. (2000). Some characteristics of rice paper of Vietnamese traditional food (Vietnamese spring rolls)- a note. Food Science and Technology Research, 6(2), 102-105.

[12] Phothiset, S., \& Charoenrein, S. (2007). Morphology and physicochemical changes in rice flour during rice paper production. Food Research International, 40, 266- 272.

[13] El- Hissewy, A. A., El-Kady, A. A., \& Lásztity, R. L. (1992). A study on the cooking and eating quality characteristics of some Egyptian rice varieties. Periodica Polytechnica Chemical Engineering, 36, 3-11.

[14] Oko, A. O., Ubi, B. E., \& Dambaba, N. (2012). Rice cooking quality and physico-chemical characteristics- a comparative analysis of selected local and newly introduced rice varieties in Ebonyi State, Nigeria. Food and Public Health, 2, 43- 49.

[15] Jobling, S., (2004). Improving starch for food and industrial applications. Current Opinion in Plant Biology, 7, 210- 218.

[16] Pitiphunpong, S., Suwannaporn, P., (2009). Physicochemical properties of KDML 105 rice cultivar from different cultivated location in Thailand. Journal of the Science of Food and Agriculture, 89, 2186- 2190.

[17] Cham, S., \& Suwannaporn, P. (2010). Effect of hydrothermal treatment of rice flour noodles quality. Journal of Cereal Science, 51 (3), 284-291.

[18] Colussi, R., Pintoa, V. Z., El Halal, S. L. M. et al. (2014). Structural, morphological, and physicochemical properties of acetylated high-, medium-, and low-amylose rice starches. Carbohydrate Polymers, 103, 405- 413.

[19] Dutta, H., Mahanta, C. L., \& Singh, V. (2015). Changes in the properties of rice varieties with different amylose content on dry heat parboiling. Journal of Cereal Science, 65, 227- 235.

[20] Dutta, H., \& Mahanta, C. L. (2012). Effect of hydrothermal treatment varying in time and pressure on the properties of the parboiled rice with different amylose content. Food Research International, 49, 655- 663.

[21] Shittu, T. A., Olaniyi, M. B., Oyekanmi A. A., \& Okeleye, K. A. (2012). Physical and water absorption characteristics of some improved rice varieties. Food Bioprocess Technology, 5, 298- 309 .

[22] Zhu, L. J., Liu, Q. Q., Sang, Y. J., Gu, M. H., \& Shi, Y. C. (2010). Underlying reasons for waxy rice flours having different pasting properties. Food Chemistry, 120, 94- 100.

[23] Patindol, J., Newton, J., \& Wang, Y. J. (2008). Functional properties as affected by laboratory scale parboiling of rough rice and brown rice. Journal of Food Science, 73, 370-377. 
[24] Mir, S. A., Bosco, S. J. D. (2013). Effect of soaking temperature on physical and functional properties of parboiled rice cultivars grown in temperate region of India. Food and Nutrition Sciences, 4, 282-288.

[25] Livingstone, A. S., Feng, J. J., \& Malleshi, N. G., (1993). Development and nutritional quality evaluation of weaning foods based on malted, popped and dried wheat and chickpea. International Journal of Food Science \& Technology, 28, 3543.

[26] Mishra, G., Joshi, D. C. \& Panda, B. K. (2014). Popping and puffing of cereal grains- a review. Journal of Grain Processing and Storage, 1, 34-46.

[27] Chinnaswamy, R., \& Bhattacharya, K. R. (1986). Pressure parboiled rice-A new base for making expanded rice. Journal of Food Science and Technology, 23, 1-6.

[28] Shashikala, I. S., Vasudeva, S., \& Ali, S. Z. (2005). Changes in physicochemical properties of Basmati paddy upon parboiling. Trends in Carbohydrate Chemistry, 9, 53-59.

[29] Hsieh, F, \& Bor, S. L. (1991). Breakfast rice cereals and baby foods - Rice snack foods. In: Rice utilization, $2^{\text {nd }}$. ed, Bor SL (ed). Van Nostrand Rienhold, New York, USA, Vol 2, pp 177194, 225-249.

[30] Dronzek, B. L., Wang, P. H. \& Bushuk, W. (1972). Scanning electron microscopy of starch from sprouted wheat. Cereal Chemistry, 49(1), 232-239.

[31] AOAC (2007). Association of Official Analytical Chemist. Official methods of analysis. (18 ${ }^{\text {th. }}$ ed). Washington, DC USA.

[32] Juliano, B. O. (1971). A simplified assay for milled rice amylose. Cereal Science Today, 16, 334-360.

[33] Englyst, H. N., Kingman, S. M., Cummings, J. H. (1992). Classification and measurement of nutritionally important starch fractions. European Journal of Clinical Nutrition, 46, S33-S50.

[34] Brookfield Manual (1998) Brookfield Manual Operating Instruction. No. M/98-211-B0104. Brookfield Engineering Laboratories Inc., Middleborough.

[35] McGurie, R. G. (1992). Reporting of objective color measurements. HortScience, 27, 1254-1255.

[36] ASTM (2010). American Society for Testing Materials, Standard Test Method for Tensile Properties of Thin Plastic Sheeting, ASTM D882-88 of Materials, Annual Book of ASTM. Standard, Philadelphia. p. 182-190.

[37] SAS. (1996). SAS/STAT1 user's guide, version 8. Cary, NC: SAS Inst, Inc.

[38] Chang, Sh., Yang, H. (1992). Thermal processing effects on rice characteristics. Food Structure, 2, 373-382.

[39] Lorlowhakarn, K., \& Naivikul, O. (2006). Modification of rice flour by heat moisture treatment (HMT) to produce rice noodles. Kasetsart Journal (Natural Science), 40 (Suppl.), 135- 143.

[40] Bhattacharya, K. R., \& Ali, S. Z. (1985). Changes in rice during parboiling and properties of parboiled rice. in: Advances in Cereal Science and Technology, 8, 105-67.

[41] Wongsa, J., Uttapap, D., Lamsal, B. P., \& Rungsardthong, V. (2016). Effect of puffing conditions on physical properties and rehydration characteristic of instant rice product. International Journal of Food Science and Technology, 51, 672- 680.

[42] Bhattacharya, K., (2004). Parboiling of rice. In: Rice Chemistry and Technology, Elaine, T. (Ed.). American Association of Cereal Chemists, Inc, St. Paul, Minnesota, pp. 329-394.

[43] Nessreen, N. B., Ammar, A. K., \& Ezzat, A. (2014). Study of some cooking and eating quality characters on some Egyptian rice genotypes. Agricultural Sciences Publications, 59, 77- 82.

[44] Buggenhout, J., Brijs, K., \& Delcour, J. A. (2013). Impact of processing conditions on the extractability and molecular weight distribution of proteins in parboiled brown rice. Journal of Cereal Science, 58, 8-14.

[45] Jorgen, H., Barbro, H., Inger, B., Ann-Charlotte, I. (1987) The effect of various thermal processing on the glycemic response to whole grain wheat in human and rats. Journal of Nutrition, $119,1631-1638$.

[46] Chitra, M., Singh, V. \& Ali, S. Z. (2010). Effect of processing paddy on digestibility of rice starch by in vitro studies. Journal of Food Science and Technology, 47(4), 414-419.

[47] Pathmanathapillai, D., Prabhaharan, M. \& Balakumar, S. (2016). Effects of the various parboiling methods on the proximate composition, amylose and resistant starch of two rice varieties from Sri Lanka. Imperial Journal of Interdisciplinary Research, 2, 295-300.

[48] Deepa, G., Singh, V., \& Naidu, K. A. (2010). A comparative study on starch digestibility, glycemic index and resistant starch of pigmented ('Njavara' and 'Jyothi') and a nonpigmented ('IR 64') rice varieties. Journal of Food Science and Technology, 47, 644-649.

[49] Rosario, S., Jayashree, A., (2000). Effect of domestic processing methods on the starch, non-starch polysaccharide and in vitro starch and protein digestibility of three varieties of rice with varying level of amylose. Food Chemistry, 70, 107111.

[50] Vaidya, R. H., \& Sheth, M. K. (2011). Processing and storage of Indian cereal and cereal products alters its resistant starch content. Journal of Food Science and Technology, 48, 622627.

[51] Kumar, S. \& Prasad, K. (2013). Effect of paddy parboiling and rice puffing on physical, optical and aerodynamic characteristics. International Journal of Agriculture and Food Science Technology, 4, 765- 770.

[52] Xue, J. \& Ngadi, M. (2006). Rheological properties of batter systems formulated using different flour combination. Journal of Food Engineering, 77, 334-341.

[53] Phattra, B., \& Maweang, M. (2015). Effects of natural fermentation on the rice slurry properties related to rice paper production. Journal of Food Science and Agricultural Technology, 1, 22-25.

[54] Rohaya, M. S., Maskat, M. Y., \& Ma'aruf, A. G. (2013). Rheological properties of different degree of pregelatinized rice flour batter. Sains Malaysiana, 42, 1707-1714.

[55] Kuenchan, N. N., Taewee, T. \& Piyarat, S. (2009). Crystallinity and rheological properties of pregelatinized rice starches differing in amylose content. Starch, 61, 101-108. 
[56] Islam, M. R., Shimizu, M., \& Kimura, T. (2004). Energy requirement in parboiling and its relationship to some important quality indicators. Journal of Food Engineering, 63, 433-439.

[57] Hapsari, A. H., Kim, S-J., Eun, J-B. (2016). Physical characteristics of parboiled Korean glutinous rice (Olbyeossal) using a modified method. LWT - Food Science and Technology, 68, 499-505.

[58] Takahashi, T., Miura, M., Ohisa, N., Mori, K., \& Kobayashi, S. (2005). Heat treatments of milled rice and properties of the flours. Cereal Chemistry, 82, 228-232.

[59] Lamberts, L., Brijs, K., Mohamed, R., Verhelst, N., \& Delcour, J. A. (2006). Impact of browning reactions and bran pigments on color of parboiled rice. Journal of Agricultural and Food Chemistry, 54, 9924-9929.

[60] Detduangchan, N., Sridach, W., \& Wittaya, T. (2014). Enhancement of the properties of biodegradable rice starch films by using chemical crosslinking agents. International Food Research Journal, 21, 1225-1235.

[61] Guilbert, S., Gontard, N. \& Cuq, B. (1995). Technology and applications of edible protective films. Packaging Technology and Science, 8, 339-346.
[62] Chayapham, O., Uttapap, D., Puttarnlek, Ch., \& Rungsardthong, V. (2008). Improvement of Rice Paper Quality by Mixing Rice Flour with Canna Starch. Kmutt Research \& Development Journal, 31, 245-260.

[63] Bertuzzi, M. A., Gottifredi, J. C., \& Armada, M. (2012). Mechanical properties of a high amylose content corn starch based film, gelatinized at low temperature. Brazilian Journal of Food Technology, 15, 219-227.

[64] Cabrera-Chávez, F., Calderón de la Barca, A. M., Islas-Rubio, A. R., Marti, A., Marengo, M., Pagani, M. A., Bonomi, F., \& Iametti, S. (2012). Molecular rearrangements in extrusion processes for the production of amaranth-enriched, GlutenFree rice pasta. LWT-Food Science and Technology, 47, 421426.

[65] Sim, B. J., Lucas, P. W., Pereira, B. P. \& Oates, C. G. (1993). Mechanical and sensory assessment of the texture of refrigerator-stored spring roll pastry. Journal of Texture Studies, 24, 27-44.

[66] Fellows, P. (2000). Processing Technology Principles and Practice. $2^{\text {nd }}$. Edition, Woodhead Publishing Limited and CRC Press LLC, Washington DC. 